\title{
RT-PCR technique and its applications. State-of the-art*
}

\author{
T. Malewski ${ }^{1}$ A. Malewska ${ }^{2}$ and R. Rutkowski ${ }^{2}$ \\ ${ }^{1}$ Institute of Genetic and Animal Breeding, Polish Academy of Sciences \\ Jastrzębiec, 05-552 Wólka Kosowska, Poland \\ ${ }^{2}$ Muzeum and Institute of Zoology, Polish Academy of Sciences \\ Wilcza 64, 00-679 Warsaw, Poland
}

(Received 19 February 2003; revised version 28 April 2003; accepted 15 July 2003)

\begin{abstract}
The reverse transcription polymerase chain reaction (RT-PCR) is one of the most sensitive methods for the detection and quantitation of mRNA. It is widely used for quantification of mRNA levels and is useful tool for basic research, agriculture, medicine and biotechnology. Introduction of Real-time technique significantly improves rapidity, sensitivity, specificity and reproducibility of RTPCR method. Real-time PCR detects and quantifies nucleic acids even from live and dead pathogens or cells. This review discusses the background, advantages and limitations of conventional and Realtime RT-PCR methods for quantitation of gene expression and its application in basic, agricultural and biomedical research.
\end{abstract}

KEY WORDS: RT-PCR, Real-time PCR, gene expression, molecular diagnostics, mRNA

\section{INTRODUCTION}

Many cellular processes concerning survival, growth and differentiation are reflected in altered patterns of gene expression and the ability to measure transcription levels of specific genes has always been central to any research into gene function. The emergence of molecular medicine and veterinary has resulted in the increased use of techniques able to quantitate levels of RNA. Such applications

\footnotetext{
* Partly supported by the State Committee for Scientific Research, Grant No. 3 P06D 01723
} 
are wide-ranging and include procedures designed to quantify the regulation and expression of drug resistance markers in tumour cells (Ramachandran and Melnick, 1999), monitor responses to chemotherapy (Desjardin et al., 1999), provide a molecular assessment of tumour stage (Bustin and Dorudi, 1998), detect circulating tumour cells in cancer patients (Ghossein and Rosai, 1996), detect bacterial (Hill, 1996) and viral (Holodniy, 1994) pathogens. It is the most sensitive and the most flexible of the quantification methods (Wang and Brown, 1999) and can be used to characterize patterns of mRNA expression, to analyse RNA structure and clone full-length complementary DNA (cDNA). The focus on maximizing sensitivity has led to the development of semi-nested (Wasserman et al., 1999), nested (Israeli et al., 1994; Soeth et al., 1996), and even three-step nested (Funaki et al., 1998) RT-PCR techniques.

\section{CHARACTERISTICS OF RT-PCR REACTION}

RT-PCR analysis consists of four steps:

- isolation and purification of RNA

- cDNA synthesis based on RNA template

- amplification of a part of cDNA using PCR

- estimation of product quantity.

The scheme of analysis is presented on Figure 1. Isolation and purification of RNA are based on two methods. The first one is classical Chomczyński and Sacchi method (1987). RNA is deproteinized in mixture of guanidine thiocyanate and phenol. The second method is based on absorption of RNA on silica dioxide in solutions of wide range of ionic strength, washing to remove contaminants, and elution by solutions with low ionic strength and particular $\mathrm{pH}$. This method allows purification of RNA from main inhibitors of enzymatic reaction, proteins and polysaccharides (Cheung et al., 1994; Rasool et al., 2002). Presently there are many modifications of these two methods. The comparing experiments had indicated that they assured similar quantity of RNA of comparable purity (Gaurino et al., 1997; Rasool et al., 2002). Till now many biochemical companies have designed kits for extraction either total DNA and mRNA from tissues and cells (Sigma Aldrich, Ambion, Quigen et al.). Moreover there are commercially available kits for RNA isolation directly from blood samples, for example RNAqueous-Blood Module (Ambion). The kit guaranteed yield of 200ng of total RNA from 200-300 $\mu 1$ of blood.

The second step in RT-PCR analysis is the reverse transcription of the RNA template into cDNA by RNA-dependent DNA polymerase (reverse transcriptase, RT). RNA transcripts can exhibit significant secondary structure that affects the ability of the RNA-dependent reverse transcriptase to generate transcripts. There are com- 
monly used reverse transcriptases of two origins: - a myeloblastosis virus reverse transcriptase (AMVRT) and moloney murine leukaemia virus reverse transcriptase (MMLV-RT). AMV-RT is more robust than MMLV-RT (Brooks et al., 1995) and can help eliminate problems associated with RNA secondary structure. MMLV-RT have significantly less RNAseH activity than AMV-RT (Gerard et al., 1997) what allows synthesis of long amplicons and may be a better choice for amplification of full-length cDNA molecules. The RT step can be primed using specific primers, random hexamers or oligo(dT) primers. The use of specific primers decreases background priming, whereas the use of random and oligo(dT) primers maximizes the number of mRNA molecules that can be analysed from a small sample of RNA.

Obtained in the first step cDNA is used as a template for standard

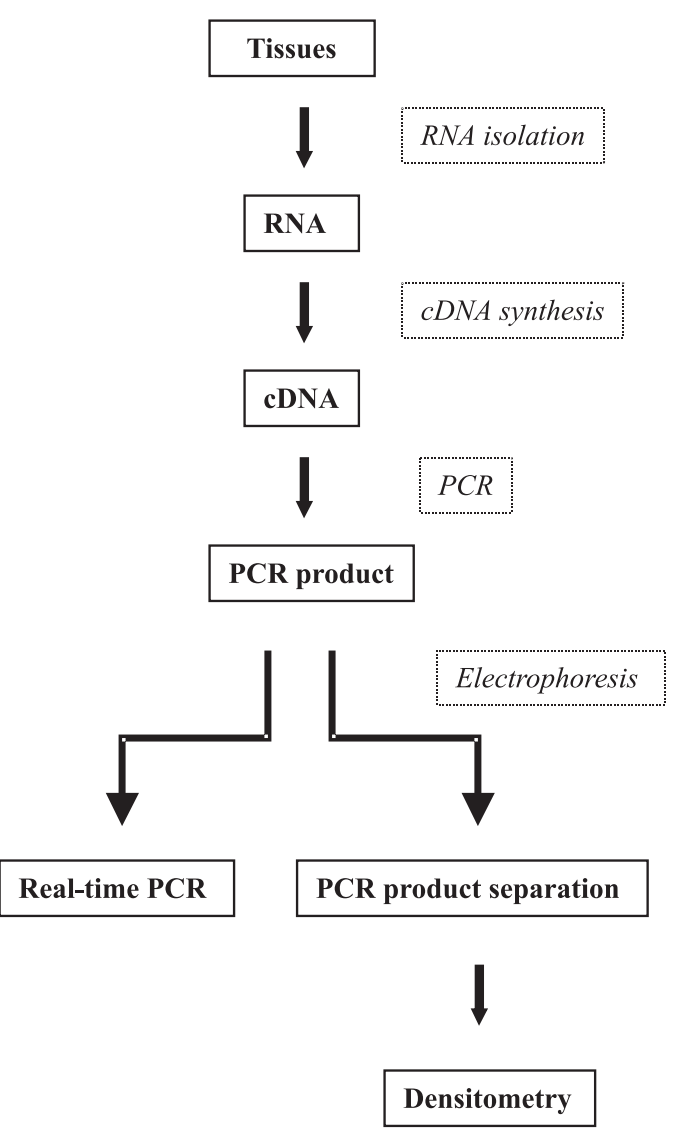

Figure 1. Standard RT-PCR reaction setup $\mathrm{PCR}$ reaction. Some experiments demands only detection of specific RNA molecule or statement of absence of that molecule. For this type of experiment a single tube ('one-enzyme/one-tube') system is useful, utilizing Thermus thermophilus (Tth) polymerase, a DNA polymerase with intrinsic RT, but no RNase H, activity. This assay uses bicine buffers containing $\mathrm{Mn}^{2+}$ ions that are compatible with both RT and subsequent PCR reaction (Chiocchia and Smith, 1997). There is also evidence that RT-PCR reactions using Tth polymerase may be more robust and resistant to inhibitors present in biological specimen (Poddar et al., 1998). The main drawbacks of this system are that sensitivity of Tth polymerase is two orders of magnitude lower than that of Taq polymerase (Grabko et al., 1996) so this system is not as sensitive as two-enzyme procedures, and presence of $\mathrm{Mn}^{2+}$ ions reduces the fidelity of nucleotide incorporation (Fromant et al., 1995). The aim of most experiments is quantitative measurement of target gene expression. Results of quantitative measurements can be presented as relation 
of target gene to reference gene mRNA copy number or as absolute mRNA copy number. As references are chosen genes exhibiting constants expression level in the majority of tissues, for example: glyceraldehyde-3-phosphate dehydrogenase (GAPDH), $\beta$-actin, or 18S rRNA. One of examples of measurement of relative expression level of homeotic Dlx5 gene in mice mammary gland is presented on Figure 2.

For measurement of absolute mRNA copy number is used competitive PCR, Real-time PCR and ELISA-PCR methods often called quantitative RT-PCR (QRTPCR). Performing QRT-PCR analysis is necessary pay attention to contamination of RNA samples with DNA traces because synthesis of PCR products can begin not only on cDNA template but on genomic DNA as well. This problem can be solved for conventional or competitive, but not in real-time PCR by careful selection of primers. Selection of primers, localized in different exons of investigated genes, allows separation of PCR product synthesised on cDNA or genomic DNA template. Limitation of this approach is frequent appearance of retropseudogenes in genomic DNA. Recently, have been published poly(A) cDNA-specific RT-PCR technique (PACT RT-PCR) (Folz and Nepluev, 2000), and EXACT RT-PCR (Smith et al., 2000) promising design primers which can distinguish PCR product from cDNA and genomic DNA even for templates containing retropseudogenes.

Accurate measurement of mRNA copy number is possible during exponential stage of PCR reaction. This requires choosing of appropriate amount of cDNA and
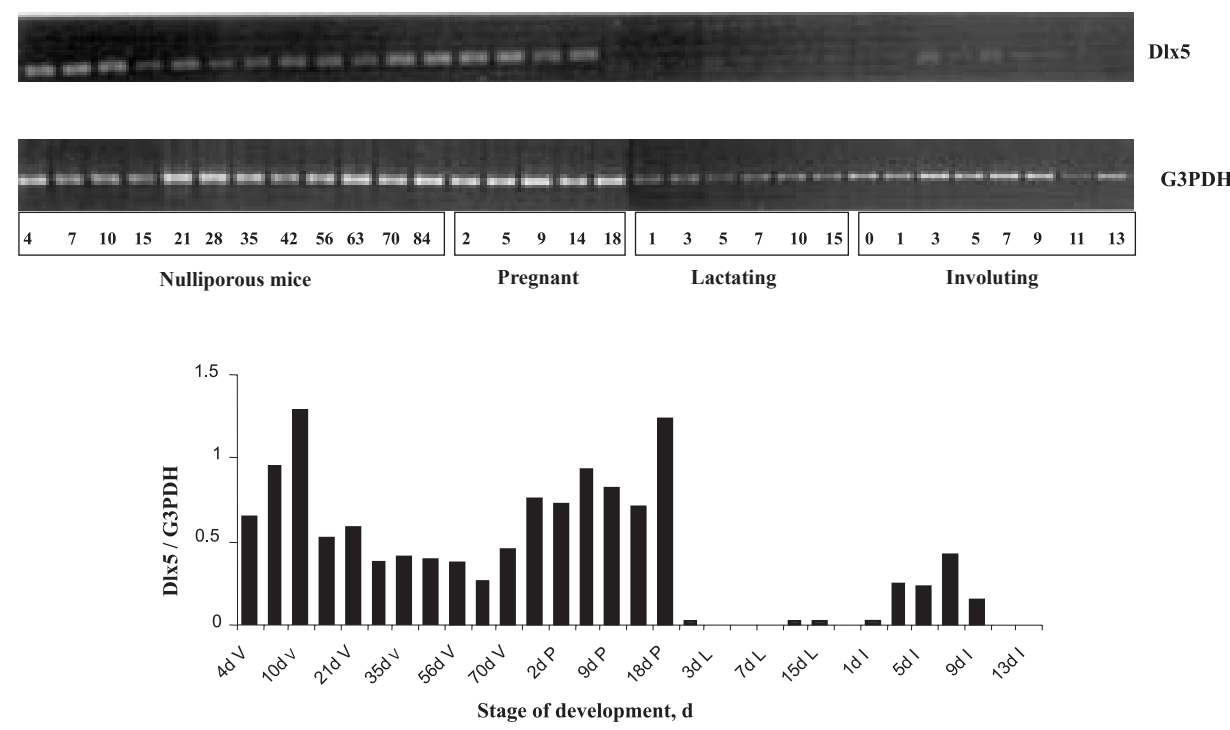

Figure 2. Measurement of relative expression of homeotic Dlx5 gene in the mammary gland of mice 
cycle number for PCR reaction. For quantifying mRNA by competitive PCR, internal standard RNA (competitor) is added in a defined quantity to the RNA sample prior to the RT reaction (Larrick, 1997). The resulting standard cDNA is coamplified with the same primers as the endogenous target sequence. To make a competitor PCR with a conventional downstream primer and a modified upstream primer is performed to give a sequence approximately $10 \%$ shorter then target sequence. The PCR product is isolated and cloned into a vector that contains strong DNA-dependent RNA-polymerase promoter sequence (T7, T3 or SP6). Appropriate RNA polymerase performs in vitro transcription of the cloned fragment. The internal standard RNA is treated with RNase-free DNase I to remove traces of plasmid DNA and finally measured by spectrophotometry. For the quantitation of the mRNA several RT reactions are prepared with the same amount of total RNA and different amounts of competitor. For the first measurements of a mRNA it is best to add competitor amounts which differ by factor 10 to determine the range in which the transcript amount is to be found. If that is known, factor 2-2.5 between the standard amounts gives more accurate results. This method allows measurement of small differences (as low as factor 2) in mRNA amount between RNA samples. The main advantage of the method is possibility of estimation of PCR products either during exponential reaction stage as well as during plateau stage what greatly broadens range of RNA quantities, which could be able to measure (Jungerman, 1997).

Considerable progress in QRT-PCR was achieved after introduction of Real-time PCR. The comparison of several QRT-PCR methods showed that, techniques based on gel electrophoresis and densitometry of PCR products had variability coefficient much greater (10-19\%) than Real-time (even 2\%) (Klein et al., 2001; Ylikoski et al., 2001). Real-time RT- PCR quantitates the initial amount of the template most specifically, sensitively and reproducibly, and actually is a preferable alternative to other forms of quantitative RT-PCR which detects the amount of final amplified product. Real-time PCR monitors the fluorescence emitted during the reaction as an indicator of amplicon production during each PCR cycle (i.e. in Real-time) as opposed to the endpoint detection by competitive PCR. Real-time PCR quantitation eliminates post-PCR processing of PCR products what helps to increase throughput, reduce the chances of carryover contamination and remove post-PCR processing as a potential source of error. Real-time PCR has also much wider dynamic range (up to $10^{7}$-fold comparing with $10^{3}$-fold of conventional RT-PCR) (Klein, 2002). This means that a wide range of ratios of target and normalizer can be assayed with equal sensitivity and specificity.

Three different technologies are commonly used for Real-time PCR detection. All of them are based on the measurement of fluorescence during the PCR. The amount of emitted fluorescence is proportional to the amount of PCR product and enables the monitoring of the PCR reaction. The resulting PCR curve is used to define the exponential phase of the reaction, which is a prerequisite for accurate 
calculation of the initial copy number at the beginning of the reaction. The simplest and cheapest principle is based on intercalation of double-stranded DNA-binding dyes. Non-sequence specific agents (SYBR-green I or ethidium bromide) intercalate in a minor groove of DNA. After intercalation fluorescence significantly increase and is proportional to amount of double-stranded DNA generated by PCR. Accurate quantitation can be obtained over a large range of initial template amounts if conditions are optimal. SYBR Green has been shown to be linear over a $10^{8}$-fold range of template concentrations, sensitive down to 10 copies (Bustin, 2000). This technology can be easily applied to already establish PCR assays and does not need any additional fluorescence-labelled oligonucleotide. The major problem with SYBR Green-based detection is that non-specific amplifications cannot be distinguished from specific amplifications. Therefore, these assays require careful optimization of the PCR conditions and a clear differentiation between specific and non-specific PCR products using melting-curve analysis. The other two principles are based on the introduction of an additional fluorescence-labelled probe. The TaqMan probes (Heid et al., 1996) and molecular beacons (Tyagi and Kramer, 1996; Tan et al., 2000) use the fluorogenic 5' exonuclease activity of Taq polymerase to measure the amount of target sequences in cDNA samples. The TaqMan assay exploits the 3'-5' exonuclease activity of Taq polymerase to cleave a TaqMan probe during PCR. The TaqMan probe is a 20-30 bases long oligonucleotide that contains a reported fluorescent dye at the 5' and a quencher dye at the 3' end (because the 3' end is blocked, it cannot act as a primer). When irradiated, the excited fluorescent dye transfers energy to the nearby quenching dye molecule rather than fluorescing (this is called FRET, Förster or fluorescence resonance energy transfer). TaqMan probes are designed to anneal to an internal region of a PCR product. When the polymerase replicates a template on which a TaqMan probe is bound, its 5' exonuclease activity cleaves the probe. These ends the activity of quencher (no FRET) and the reporter dye starts to emit fluorescence, which increases in each cycle proportional to the rate of probe cleavage. Molecular beacons also contain fluorescent (FAM, TAMRA, TET, ROX) and quenching dyes (typically DABCYL) at either end but they are designed to adopt a hairpin structure while free in solution to bring the fluorescent dye and the quencher in close proximity for FRET to occur. It is designed to have two arms with complementary sequences that form a very stable hybrid or stem. The close proximity of the reporter and the quencher in this hairpin configuration suppresses reporter fluorescence. When the beacon hybridizes to the target during the annealing step, the reporter dye is separated from the quencher and the reporter fluoresces (FRET does not occur). Molecular beacons remain intact during PCR and must rebind to target every cycle for fluorescence emission. This will correlate to the amount of PCR product available (Knemeyer et al., 2000; Liu et al., 2002). Both TaqMan probes and molecular beacons allow detection of multiple DNA species (multiplexing) by use of different reporter dyes on different 
probes/beacons. By multiplexing, both the target and endogenous control can be amplified in single tube.

Accumulation of PCR products is detected by monitoring the increase in fluorescence of the reporter dye. TaqMan assay uses universal thermal cycling parameters and PCR reaction conditions. Because the cleavage occurs only if the probe hybridizes to the target, the fluorescence detected originates from specific amplification. The process of hybridization and cleavage does not interfere with the exponential accumulation of the product. The slope of the log-linear phase is a reflection of the amplification efficiency. For the slope to be an indicator of real amplification (rather than signal drift), there has to be an inflection point. This is the point on the growth curve when the log-linear phase begins. It also represents the greatest rate of change along the growth curve. The important parameter for quantitation of PCR product is the threshold cycle $\left(\mathrm{C}_{\mathrm{T}}\right)$. The threshold cycle value is the cycle when the system begins to detect the increase in the signal associated with an exponential growth of PCR product during the log-linear phase. The higher the initial amount of cDNA, the sooner accumulated product is detected in the PCR process, and the lower the $\mathrm{C}_{\mathrm{T}}$ value. Correct choice of threshold, which determine the $\mathrm{C}_{\mathrm{T}}$ value, is one of the most important elements in Real-time PCR. It should be placed above any baseline activity and within the exponential increase phase. Software allows determination of the cycle threshold by a mathematical analysis of the growth curve.

\section{APPLICATIONS OF RT-PCR IN MOLECULAR DIAGNOSTIC}

Clinical microbiology, virology and food microbiology are important fields for Real-time PCR applications. Hundreds of assays have been published for the detection and quantification of various infectious agents (Jordan, 2000). However, critical and strict evaluation of newly developed assays is a prerequisite to obtain reliable data. Real-time PCR assays are less time- and labour-intensive (Hein et al., 2001). It detects and quantifies nucleic acids from live and dead pathogens, whereas classical microbiological assays count only live pathogens. Most infectious agents are characterized by a high mutation rate, which can influence the viral load estimation dramatically (Fend et al., 2000). This problem can be overcome by using highly conserved regions for assay development. On the other hand, sequence variations provide the basis for the development of subtype-specific assays. In combination with a multiplex approach this an elegant tool to monitor different strains within a patient or population. Molecular beacons have the advantage for pathogen quantification as up to four different fluorescent dyes can be detected and quantified simultaneously (Ohyama et al., 2000). The simultaneous quantification of different targets decreases both the cost and turn-around time of the assay and, if the assay 
is carefully optimized, increases the reliability of the obtained data. The multiplex approach provides a benefit, in that pipetting errors are minimized and both nucleic acids are amplified simultaneously under the same conditions. In comparison with monoplex approaches, the duplex assay results in higher precision and accuracy of the obtained data (Fend et al., 2000; Klein et al., 2002). Nevertheless, duplex or multiplex assays are complex and require a high degree of optimization work. Primer matrix assays for all primer pairs are necessary to increase the sensitivity of the assay and identify the lowest primer concentration that has no effect during the exponential phase of the reaction (Fend et al., 2000; Ohyama et al., 2000; Klein et al., 2002). Internal standardization in multiplex approaches is also an important aspect in applications requiring quality assurance (Baugh et al., 2001).

\section{Applications in virology}

RNA is a genetic material of great number of viruses, which are etiological factors of human, animals and plants infectious diseases. Introduction of RT-PCR technique allowed achieving considerable progress in examination of diseases caused by RNA viruses, for example HIV, hepatitis virus, enteroviruses, rabies virus. The replication of nucleic acids is one of the first steps in virus development, thus RT-PCR method allows detecting of infection even before organism have begun to produce specific antibodies, thus before seroconversion. The measurement of virus RNA quantity allows the estimation of viremy level and the monitoring of antiviral therapy efficiency. In diagnostics of virus diseases RT-PCR was applied in three main cases:

- detection of invasion with short period between contact and appearance of disease symptoms

- lack of serological tests

- epidemiological investigation.

RT-PCR is often used for detection of enteroviruses caused diseases. The clinical picture dose not allow differentiate diseases caused by enteroviruses and another kind of viruse infection. Till RT-PCR has been introduced diagnosis of enteroviruses infection was based on isolation of virus from faeces or cerebrospinal fluid or on analysis of antibody titre in serum. Enteroviruses isolation is time-consuming process persisting at least 4 - 8 days (Chonmaittree, 1982). Serological diagnostics was found to be difficult because of great antigenic variation of enteroviruses, appearance of heterotypical immunological response and lack of mutual antigenic determinant - laboratory confirmation of infection takes at least two weeks. These methods are appropriated in epidemiological investigations but are not satisfactory for diagnosis. RT-PCR technique help solve many of these problems. High homology of RNA sequences on non-translating 5'-end of genome (5'-UTR) makes possible to design primers for detection of majority if not all of enteroviruses. Moreover it is 
possible to design primers for detection of limited amounts of serotype (group- or strain specific primers). RT-PCR has been found even more sensitive in detection of enteroviruses than cell cultures (Rotbart, 1990; Sawyer, 1994). Short time of analysis is the main advantage of RT-PCR method. It was convinced that time from sample preparing till evaluation of reaction result takes about $5 \mathrm{~h}$, at sensitivity $94.7 \%$, specificity $94.7 \%$ and repeatability $99 \%$ (Rotbart, 1997). Additional advantage of RT-PCR is small volume of serum or cerebrospinal fluid is also essential for analysis - about $50 \mu 1$ (Kammerer, 1994). Introduction of heat labile form of the enzyme uracil DNA glycosylase (UNG) for amplicon contamination control and an RT-PCR enzyme mixture, enabling a one tube/one step amplification (Taggart et al., 2002) further increased capacities of RT-PCR method. Read et al. (1997) has analysed usefulness of RT-PCR for diagnostic of aseptic neuroinfection. Authors indicated high repeatability of the test and its exceptional usefulness in diagnostic of infection caused by coxackieviruses type A; 1 and 6 , which does not proliferate in cell lines - it is impossible to use classical diagnostic method. RT-PCR is also used in diagnostics and monitoring of hepatitis virus type $\mathrm{C}$ and AIDS. Genetic material of hepatitis virus type C (HVC) is a single stranded RNA molecule 9500 base pair long. The main screening test for HCV laboratory diagnostic is ELISA assay, which detect HVC antigen. Although even use of III generation of ELISA test time between HVC infection and symptoms appearance or seroconversion takes 3 to 6 weeks (Decker and Troonen, 1997). During this period HVC could be detected only by RT-PCR. It is estimated that RT-PCR is able to detect as low as 10 molecules of HCV-RNA, even after one week post-infection. HCV-RNA detection in practise is used for screening of patients anti-HCV negative patients from high risk groups, detection of infection in patient whit normal aminotransferase activity, qualification of pacients for anti-virus treatment and control of treatment efficiency. Recently, Roche Diagnostic Inc., designed COBAS AmpliScreen HCV and AMPLICOR HVC RT-PCR kits for diagnostic of HCV as well as kits for AIDS diagnostic, which were in 2001 year allowed by FDA for clinical applications on USA market. In year 2002 the permit was extended on COBAS TaqMan Analyser.

\section{Applications in oncology}

Major challenges of clinical oncology for assay techniques are sensitivity and level of discrimination of the assay. The technical sensitivity of an optimized Realtime PCR assay itself is high ( $<5$ copies per reaction), but the maximal input of nucleic acid during sample preparation and per PCR reaction is the limiting step. One of example of successful application of RT-PCR in clinical oncology is monitoring of residual disease after leukaemia treatment (Kantarjian et al., 2003; Pine et al., 2003). The end of remission period is marked by appearance of malignant cells in blood. Appearance of malignant cells during remission period gave name of residual 
disease. The detection and quantification of chromosomal translocations by Real-time PCR has been applied to monitor minimal residual disease (Pongers-Willemse et al., 1998) or to show graft-versus lymphoma effects (Mandigers et al., 1998). More then $90 \%$ patients with chronic myeloid leukaemia (CML), $20 \%$ of adult and $5 \%$ of children with acute lymphoblastic leukaemia (ALL) has Philadelphia chromosome $(\mathrm{Ph})$. This chromosome appears as result of reciprocal translocation of chromosome 22 in breakpoint cluster region (BCR) and chromosome 9 on the 5 '-end of $\mathrm{ABL}$ gene. Joint product of fused $\mathrm{BRC}$ and $\mathrm{ABL}$ is transcribed, and transcription product is alternative spliced. Alternative splicing of primary transcript generates three types of mRNA with following exon sequence: - e11-e12-e13(b2)-a2-a3-a4 (b2a2 product), e11-e12-e13(b2)-e14(b3)-a2-a3-a4 (b3a3 product), and e1-a2-a3-a4 (e1a2 product) (Jungerman, 1997). Scheme of alternative splicing of BCR-ABL primary transcript is presented at Figure 3. The majority of CML patients indicate presence of $\mathrm{b} 2 \mathrm{a} 2$ or $\mathrm{b} 3 \mathrm{a} 2$ splicing products and about $70 \%$ of patients with ALL$\mathrm{Ph}(+)$ phenotype indicates presence of e1a2a. This is the excellent marker because jointed BCR-ABL product is present only in lymphocytes of patients suffering leukaemia. Expression of ABL gene proceeds in all leukocytes what makes possible to use its mRNA as an internal standard. Final result of RT-PCR analysis is presented as percentage BCR-ABL quantity in comparison to ABL. Value below $0.02 \%$ indicate that patient is still in remission, $0.02-0.5 \%$ indicate end of remission period and return of disease (Cross, 1993; Lion, 1993).

Products of alternatively spliced BCR-ABL primary transcript

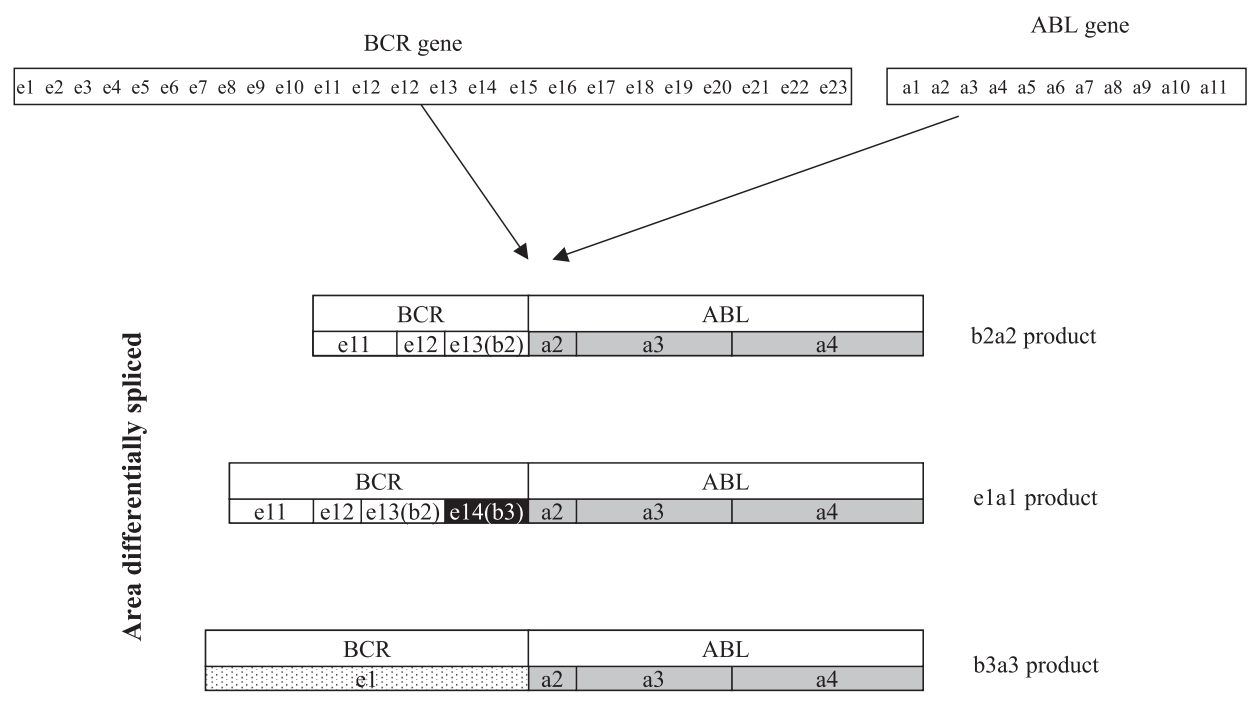

Figure 3. Alternative splicing of primary BCR-ABL transcript 
Recently, new markers have been found that can detect different kinds of tumours, among them kallikreins are one of the most promising. There is strong but circumstantial evidence linking kallikreins and cancer. Prostate-specific antigen (PSA; hK3) and, more recently, human glandular kallikrein (hK2) are widely used tumour markers for prostate cancer. Three other kallikreins, hK6, hK10, and hK11, are emerging new serum biomarkers for ovarian and prostate cancer diagnosis and prognosis. Several other kallikreins are differentially expressed at both the mRNA and protein levels in various endocrine-related malignancies, and they have prognostic value (Diamandis et al., 2002). Tyrosinase can be a marker of melanoma. Tyrosinase mRNA in blood was detected in $76 \%$ of IIB and $66 \%$ stage III patients. The presence of tyrosinase mRNA in blood was correlated with a shorter survival (P: 0.03) and in multivariate analysis was an independent prognostic factor for relapse (Gogas et al., 2002).

Real-time RT-PCR significantly simplifies and accelerates the process of mRNA quantification. The use of appropriate standard curves make possible easily calculates absolute copy numbers of mRNA. Moreover, Real-time RT-PCR is readily standardized making the comparison of results from different laboratories, templates from different samples and clinical samples from different patients easier and more reliable. Therefore, Real-time RT-PCR must be the method of choice for any experiments requiring sensitive, specific and reproducible quantification of mRNA

\section{REFERENCES}

Baugh L R., Hill A.A., Brown E.L., Hunter C.P., 2001. Quantitative analysis of mRNA amplification by in vitro transcription. Nucl. Acid Res. 29, E29

Brooks E.M., Sheflin L.G., Spaulding S.W., 1995. Secondary structure in the 3 UTR of EGF and the choice of reverse transcriptases affect the detection of message diversity by RT-PCR. Biotechniques 19, 806-815

Bustin S.A., 2000. Absolute quantification of mRNA using real-time reverse transcription polymerase chain reaction assays. J. Molecular Endocrinol. 25, 169-193

Bustin S.A., Dorudi S., 1998. Molecular assessment of tumour stage and disease recurrence using PCR-based assays. Mol. Med. Today 4, 389-396

Chiocchia G., Smith K.A., 1997. Highly sensitive method to detect mRNAs in individual cells by direct RT-PCR using Tth DNA polymerase. Biotechniques 22, 312-318

Cheung R.C., Matsui S.M., Greenberg H.B., 1994. Rapid and sensitive method for detection of hepatitis C virus RNA by using silica particles. J. Clin. Microbiol. 32, 2593-2597

Chomczynski P., Sacchi N., 1987. Single-step method of RNA isolation by acid guanidinium thiocyanate-phenol-chloroform extraction. Anal. Biochem. 162, 156-159

Chonmaitree T., Menegus M., Powell K.L., 1982. The clinical relevance of 'CSF viral culture'. A two-year experience with aseptic meningitis in Rochester, NY. JAMA 247, 1843-1847

Cross N.C.P., Lin F., Chase A., Bungey J., Hugness T.P., Goldmann J.M., 1993. Competitive polymerase chain reaction to estimate the number of BCR-ABL transcripts in chronic myeloid leukemia patients after bone marrow transplantation. Blood 82, 1929-1939 
Decker R., Troonen H., 1997. Diagnosing hepatitis C: overview. In: C.R. Decker, H. Troonen (Editors). Hepatitis. Abbot Diagnostics Division, Denkelheim

Desjardin L.E., Perkins M.D., Wolski K., Haun S., Teixeira L., Chen Y., Johnson J.L., Ellner J.J., Dietze R., Bates J., Cave M.D., Eisenach K.D., 1999. Measurement of sputum Mycobacterium tuberculosis messenger RNA as a surrogate for response to chemotherapy. Amer. J. Respir. Crit. Care Med. 160, 203-210

Diamandis E.P., Yousef G.M., 2002. Human tissue kallikreins: a family of new cancer biomarkers. Clin. Chem. 48, 1198-1205

Fend F., Kremer M., Quintanilla-Martinez L., 2000. Laser capture microdissection: methodical aspects and applications with emphasis on immuno-laser capture microdissection. Pathobiology $68,209-214$

Folz R.J., Nepluev I., 2000. Poly(A) cDNA-specific (PACS) RT-PCR: a quantitative method for the measurement of any poly(A)-containing mRNA not affected by contaminating genomic DNA. Biotechniques 29, 762, 764-5, 766-768

Fromant M., Blanquet S., Plateau P., 1995. Direct random mutagenesis of gene-sized DNA fragments using polymerase chain reaction. Anal. Biochem. 224, 347-353

Funaki N.O., Tanaka J., Ohshio G., Onodera H., Maetani H., Imamura M., 1998. Cytokeratin 20 mRNA in peripheral venous blood of colorectal carcinoma patients. Brit. J. Cancer 77, 1327-1332

Gerard G.F., Fox D.K., Nathan M., D’Alessio J.M., 1997. Reverse transcriptase. The use of cloned Moloney murine leukemia virus reverse transcriptase to synthesize DNA from RNA. Mol. Biotechnol. 8, 61-77

Ghossein R.A., Rosai J., 1996. Polymerase chain reaction in the detection of micrometastases and circulating tumor cells. Cancer 78, 10-16

Gogas H., Kefala G., Bafaloukos D., Frangia K., Polyzos A., Pectasides D., Tsoutsos D., Panagiotou P., Ioannovich J., Loukopoulos D., 2002. Prognostic significance of the sequential detection of circulating melanoma cells by RT-PCR in high-risk melanoma patients receiving adjuvant interferon. Brit. J. Cancer 87, 181-186

Grabko V.I., Chistyakova L.G., Lyapustin V.N., Korobko V.G., Miroshnikov A.I., 1996. Reverse transcription, amplification and sequencing of poliovirus RNA by Taq DNA polymerase. FEBS Lett. 387, 189-192

Guarino H., Goyal S.M., Murtaugh M.P., 1997. Comparison of four RNA extraction methods for the detection of porcine reproductive and respiratory syndrome virus by RT-PCR. New Microbiol. 20, 319-24

Heid C.A., Stevens J., Livak K.J., Williams P.M., 1996. Real-time quantitative PCR. Genome Res. 6, 986-994

Hein I., Klein D., Lehner A., Bubert A., Brandl E., Wagner M., 2001. Detection and quantification of the iap gene of Listeria monocytogenes and Listeria innocua by a new real-time quantitative PCR assay. Res. Microbiol. 152, 37-46

Hill W.E., 1996. The polymerase chain reaction: applications for the detection of foodborne pathogens. Crit. Rev. Food Sci. Nutr. 36, 23-173

Holodniy M., 1994. Clinical application of reverse transcription-polymerase chain reaction for HIV infection. Clin. Lab. Med. 14, 335-349

Israeli R.S., Miller W.H. Jr., Su S.L., Powell C.T., Fair W.R., Samadi D.S., Huryk R.F., DeBlasio A., Edwards E.T., Wise G.J., 1994. Sensitive nested reverse transcription polymerase chain reaction detection of circulating prostatic tumor cells: comparison of prostate-specific membrane antigen and prostate-specific antigen-based assays. Cancer Res. 54, 6306-6310

Jordan J.J., 2000. Real-time detection of PCR products and microbiology. New Technol. Life Sci. A Trends Guide, 8, 61-66

Jungerman M., 1997. Quantitative PCR and its application in haematologic molecular diagnostics (in Polish). Post. Biochem. 43, 250-256 
Kammerer U., Kunkel B., Korn I., Nested K., 1994. Nested PCR for specific detection and rapid identification of human picornaviruses. J. Clin. Microbiol. 32, 285-291

Kantarjian H.M, Talpaz M., Cortes J., O’Brien S., Faderl S., Thomas D., Giles F., Rios M.B., Shan J., Arlinghaus R., 2003 Quantitative polymerase chain reaction monitoring of BCR-ABL during therapy with imatinib mesylate (STI571; Gleevec) in chronic-phase chronic myelogenous leukemia. Clin. Cancer Res. 9, 160-166

Klein D., 2002. Quantification using real-time PCR technology: applications and limitations. Trends Mol. Med. 8, 257-260

Klein D., Leutenegger C.M., Bahula C., Gold P., Hofmann-Lehmann R., Salmons B., Lutz H., Gunzburg W.H., 2001. Influence of preassay and sequence variations on viral load determination by a multiplex real-time reverse transcriptase-polymerase chain reaction for feline immunodeficiency virus. J. Acq. Immun. Defic. Syndr. 26, 8-20

Klein C.A., Seidl S., Petat-Dutter K., Offner S., Geigl J.B., Schmidt-Kittler O., Wendler N., Passlick B., Huber R.M., Schlimok G., Baeuerle P.A., Riethmuller G., 2002. Combined transcriptome and genome analysis of single micrometastatic cells. Nat. Biotechnol. 20, 387-392

Knemeyer J.P., Marme N., Sauer M., 2000. Probes for detection of specific DNA sequences at the single-molecule level. Anal. Chem. 72, 3717-3724

Larrick J.W. (Editor), 1997. The PCR Technique: Quantitative PCR. Natick, MA, BioTechniques Books, pp. 313

Lion T., Henn T., Gaiger A., Kahls P., Gadner H., 1993. Early detection of relapse after bone marrow transplantation in patients with chronic myelogenous leukaemia. Lancet 341, 275-276

Liu J., Feldman P., Chung T.D., 2002. Real-time monitoring in vitro transcription using molecular beacons. Anal. Biochem. 300, 40-45

Mandigers C.M., Meijerink J.P., Raemaekers J.M., Schattenberg A.V., Mensink E.J., 1998. Graft-versus-lymphoma effect of donor leucocyte infusion shown by real-time quantitative PCR analysis of $\mathrm{t}(14 ; 18)$. Lancet $352,1522-1523$

Ohyama H., Zhang X., Kohno Y., Alevizos I., Posner M., Wong D.T., Todd R., 2000. Laser capture microdissection-generated target sample for high-density oligonucleotide array hybridization. Biotechniques 29, 530-536

Pine S.R., Moy F.H., Wiemels J.L., Gill R.K., Levendoglu-Tugal O., Ozkaynak M.F., Sandoval C., Jayabose S., 2003. Real-time quantitative PCR: standardized detection of minimal residual disease in pediatric acute lymphoblastic leukemia. J. Pediatr. Hematol./Oncol. 25,103-108

Poddar S.K., Sawyer M.H., Connor J.D., 1998. Effect of inhibitors in clinical specimens on Taq and Tth DNA polymerase-based PCR amplification of influenza A virus. J. Med. Microbiol. 47, 1131-1135

Pongers-Willemse M.J., Verhagen O.J., Tibbe G.J., Wijkhuijs A.J., de Haas V., Roovers E., van der Schoot C.E., van Dongen J.J., 1998. Real-time quantitative PCR for the detection of minimal residual disease in acute lymphoblastic leukemia using junctional region specific Taqman probes. Leukemia 12, 2006-2014

Ramachandran C., Melnick S.J., 1999. Multidrug resistance in human tumors - molecular diagnosis and clinical significance. Mol. Diagn. 4, 81-94

Rasool N.B., Monroe S.S., Glass R.I., 2002. Determination of a universal nucleic acid extraction procedure for PCR detection of gastroenteritis viruses in faecal specimens. J. Virol. Meth.100, $1-16$

Read S.T., Jeffery K.L.M., Bangham C.R.M., 1997. Aseptic meningitis and encephalitis: the role of PCR in the diagnostic laboratory J. Clin. Microbiol. 35, 691-696

Rotbart H.A., 1990. Diagnosis of enteroviral meningitis with the polymerase chain reaction. J. Pediat. $117,85-89$ 
Rotbart H.A., 1997. Reproducibility of AMPLICOR enterovirus PCR test results J. Clin. Microbiol. $35,3301-3302$

Sawyer M.H., Holland D., Aintablian N., Connor J.D., Keyser E.F., Waecker N.J. Jr., 1994. Diagnosis of enteroviral central nervous system infection by polymerase chain reaction during a large community outbreak. Pediat. Inf. Dis. J. 13, 177-182

Smith R.D., Ogden C.W., Penny M.A., 2001. Exclusive amplification of cDNA template (EXACT) RT-PCR to avoid amplifying contaminating genomic pseudogenes. Biotechniques 31, 776-782

Soeth E., Roder C., Juhl H., Kruger U., Kremer B., Kaltho H., 1996. The detection of disseminated tumor cells in bone marrow from colorectal-cancer patients by a cytokeratin-20-specific nested reverse-transcriptase-polymerase-chain reaction is related to the stage of disease. Int. J. Cancer 69, 278-282

Taggart E.W., Carroll K.C., Byington C.L., Crist G.A., Hillyard D.R., 2002. Use of heat labile UNG in an RT-PCR assay for enterovirus detection. J. Virol. Meth. 105, 57-65

Tan W., Fang X., Li J., Liu X., 2000. Molecular beacons: a novel DNA probe for nucleic acid and protein studies. Chemistry 6, 1107-1111

Tyagi S., Kramer F.R., 1996. Molecular beacons-probes that fluoresce upon hybridization. Nat. Biotechnol. 14, 303-308

Wang T., Brown M.J., 1999. mRNA quantification by real-time TaqMan polymerase chain reaction: validation and comparison with RNase protection. Anal. Biochem. 269, 198-201

Wasserman L., Dreilinger A., Easter D., Wallace A., 1999. A seminested RT-PCR assay for HER2/ neu: initial validation of a new method for the detection of disseminated breast cancer cells. Mol. Diagn. 4, 21-28

Ylikoski A., Karp M., Lilja H., Lovgren T., 2001. Dual-Label detection of amplified products in quantitative RT-PCR assay using lantanide labeled probes. Biotechniques 30, 832-845

\section{STRESZCZENIE}

\section{Metody RT-PCR oraz możliwości ich zastosowania}

Reakcja PCR połączona z odwrotną transkrypcją (RT-PCR ang. reverse transcription polymerase chain reaction) jest jedną z najbardziej czułych metod wykrywania obecności i pomiaru ilości mRNA. Metody RT-PCR są szeroko stosowane do pomiaru ilości mRNA w badaniach podstawowych, biotechnologii, medycynie oraz w rolnictwie. Zastosowanie techniki pomiaru ilości produktu PCR w czasie rzeczywistym (ang. Real Time PCR) znacznie zwiększyło szybkość, czułość, specyficzność oraz powtarzalność RT-PCR. Tematem pracy jest omówienie podstaw metody RT-PCR wykonywanej techniką tradycyjną oraz techniką Real Time PCR, ich zalet i ograniczeń oraz ich zastosowania do pomiaru ekspresji genów w badaniach podstawowych, rolniczych i biomedycznych. 